\title{
Contracten
} maken

\section{Contractonderhandelingen met een letter of intent: het opstellen van bedingen}

\author{
Dr. E. Pannebakker LLM*
}

\section{Inleiding 1}

Tijdens contractonderhandelingen kunnen partijen een 'letter of intent' opstellen. Zo worden de belangrijkste onderhandelingspunten op papier geregeld en krijgen de eerste afspraken een contractuele vorm. Het opstellen van een letter of intent lijkt steeds meer op een handelsgebruik.

De vraag in hoeverre de partijen aan dergelijke documenten zijn gebonden, staat zowel bij het opstellen van een letter of intent als bij de eventuele geschillen centraal. Deze vraag wordt hier niet voor het eerst aan de orde gesteld; integendeel, sinds het arrest Baris/Riezen$\mathrm{kamp}^{2}$ konden verschillende voorovereenkomsten en het leerstuk van precontractuele aansprakelijkheid op veel

* Dr. E. Pannebakker LLM is universitair docent aan de Universiteit Leiden, Instituut voor Privaatrecht. De auteur bedankt dr. mr. L.M. van Bochove voor haar taaladvies.

1. Deze bijdrage is gebaseerd op het proefschrift van E. Pannebakker, dat is verschenen als: Letter of intent in International contracting, Cambridge: Intersentia 2016.

2. HR 15 november 1957, ECLI:NL:HR:1957:AG2023, NJ 1958/67 (Baris/ Riezenkamp).

3. Zie standardarresten HR 18 juni 1982, ECLI:NL:HR:1982:AG4405, NJ 1983/723 (Plas/Valburg); HR 23 oktober 1987, ECLI:NL:HR: 1987:AD0018, NJ 1988/1017 (VSH/Shell); HR 12 augustus 2005, ECLI:NL:HR:2005:AT7337, NJ 2005/467 (CBB/JPO); latere uitspraken, inter alia HR 4 oktober 1996, ECLI:NL:HR:1996:ZC2158, NJ 1997/65 (ABB/Staat); HR 16 juni 1995, ECLI:NL:HR:1995:ZC1760, NJ 1995/705 (Shell/Van Esta Tjallingii); HR 1 maart 2013, ECLI:NL:HR:2013:BY6755, NJ 2013/142 (Greenib Car/Van Dam). aandacht rekenen in de rechtspraak, ${ }^{3}$ de wetgeving ${ }^{4}$ en de literatuur. ${ }^{5}$

In deze bijdrage worden de meest voorkomende bedingen van een letter of intent onder de loep genomen. Dat wordt gedaan aan de hand van recente ontwikkelingen, rechtsvergelijkende impressies en soft lam. Een aantal aanbevelingen over het opstellen van de letter of intent wordt geformuleerd.

4. W.H.M. Reehuis \& E.E. Slob, Parlementaire geschiedenis van het nieuwe Burgerlijk wetboek: Parlementaire stukken systematisch gerangschikt en van noten voorzien. Invoering Boeken 3, 5 en 6, Deventer: Kluwer, 1991.

5. Zie recentelijk Asser/Hartkamp \& Sieburgh 6-III 2014/391-435; I.Y.G. Blei Weissmann, Burgerlijk Wetboek Boek 6 Artikel 217, in: R.J.Q. Klomp \& H.N. Schelhaas (red.), Groene Serie Verbintenissenrecht (losbl.), Deventer: Kluwer 2017; R.P.J.L. Tjittes, De aansprakelijkheid voor afgebroken onderhandelingen - een kritisch overzicht, Rechtsgeleerd Magazijn THEMIS 2016, p. 237-268. Zie ook H. Drion, Precontractuele verhoudingen naar Nederlands recht. Preadvies voor de Vereniging voor de vergelijkende studie van het recht van België en Nederland 1967/1968, in: A.R. Bloembergen e.a. (compilatie), Geschriften van H. Drion, Deventer: Kluwer 1982, p. 231; F.W. Grosheide, Naar een juridisch statuut voor internationale intentieverklaringen? (Variaties op een bekend thema), in: B.E. Reinhartz, D. Kokkini-latridou \& F.W. Grosheide (red.), Eenvormig en vergelijkend privaatrecht, Lelystad: Koninklijke Vermande 1989, p. 119; E. Hondius (red.), Precontractual liability: Reports to the XIIIth congress, International Academy of Comparative Law, Montreal, Canada, 18-24 August 1990, Deventer: Kluwer Law \& Taxation Publishers 1991; G. Cordero Moss, The function of letters of intent and their recognition in modern legal systems, in: R. Schulze (red.), New features in contract law, München: Sellier European Law Publishers 2007, p. 139; M. Fontaine \& F. De Ly, Drafting international contracts, An analysis of contract clauses, Ardsley, New York: Transnational Publishers 2009, p. 1-57; H.-J. de Kluiver, Onderhandelen en privaatrecht, Deventer: Kluwer 1992; B. Wessels, Letters of intent, Nijmegen: Ars Aequi Libri 2010. 


\section{Contractuele bedingen die betrekking hebben op de onderhandelingsfase}

In de praktijk geven de partijen verschillende namen aan de voorbereidende overeenkomsten, zoals intentieverklaring, memorandum of understanding, term sheet, heads of agreement of voorovereenkomst. Maar de juridische gevolgen van een dergelijk document vloeien niet uit de naam voort. Dit is een kwestie van uitleg; de inhoud van een letter of intent kan onder een van de volgende rechtsfiguren vallen. Een letter of intent kan (1) een definitieve overeenkomst bevatten of (2) een stap in de onderhandelingen markeren. Ook kan een letter of intent (3) een document zonder bindend effect zijn, of (4) contractuele bedingen bevatten die uitsluitend de onderhandelingsfase betreffen. ${ }^{6}$

Deze bijdrage bespreekt het laatste type van de letter of intent: de contractuele verbintenissen die de onderhandelingspartijen creëren vóórdat ze een definitieve overeenkomst sluiten. Alle documenten die onder deze definitie vallen, worden in het navolgende letter of intent genoemd. De belangrijkste bedingen betreffende de onderhandelingsfase zijn exclusiviteit en geheimhouding, de verdeling van de kosten en de anticipatie op de aansprakelijkheid en de geschillenclausule.

\section{Exclusiviteitsbeding}

Een beding waarbij de partijen van een letter of intent overeenkomen om over dezelfde transactie niet met derden te onderhandelen, of deze niet met hen aan te gaan, wordt een exclusiviteitsbeding of een lock-out-, no shop-, no talk- of non-solicitation-clausule genoemd. Een voorbeeld luidt als volgt:

In consideration of NBM's committing time and expense to its due diligence investigation from the date of this letter until 31 fuly 2004 (the 'Lock Out Period'), DB will not discuss or negotiate mith or provide any assistance to, any third party who may be interested in purchasing the Property. ${ }^{7}$

Voor de meest praktische formulering van een exclusiviteitsbeding kan de Engelse rechtspraak ter inspiratie dienen. Daar is de rechtspraak over de exclusieve onderhandelingen vrij gedetailleerd, omdat de precontractuele afspraken in beginsel nietig zijn, tenzij deze voldoende bepaalbaar zijn om voor de rechter de inhoud daarvan vast te stellen. Een verbintenis om niet met derden te onderhandelen is derhalve naar Engels recht nietig, tenzij de periode - de tijd - van de exclusiviteit is beperkt (voor de volledigheid dient er te worden vermeld dat het

6. Fontaine \& De Ly 2009, p. 37.

7. Rb. Amsterdam 4 juli 2007, ECLI:NL:RBAMS:2007:BB7395, RCR $2008 / 21$
Engels recht ook de aanwezigheid van een tegenprestatie vereist). ${ }^{8}$ Partijen zijn nooit van plan om voor onbepaalde tijd exclusief met elkaar te onderhandelen. Dit lijkt ook voor de rechtssystemen buiten het Verenigd Koninkrijk logisch. Het verdient daarom aanbeveling de periode van de exclusieve onderhandelingen overeen te komen, tenzij de partijen het vaststellen van deze periode aan de rechter of arbiter willen laten. In beginsel eindigt de periode van exclusiviteit met het einde van de letter of intent indien deze periode kan worden vastgesteld. Zo heeft de rechter in een Engelse zaak een 'redelijke’ periode van exclusiviteit vastgesteld. ${ }^{9}$

\section{Geheimhoudingsbeding}

Een geheimhoudingsbeding wordt vaak ruim geformuleerd, bijvoorbeeld als volgt:

PARTIES mill exchange Confidential Information with the purpose for [the representatives] to act as intermediary in a potential sale project of the Eneco's pomer plant (...) whereby [the representatives]'s mork will be to find an interested buyer only and to investigate whether this potential buyer and Eneco can come to an agreement, in any form, of such a sale and purchase agreement. ${ }^{10}$

Een ruime formulering leidt niet per se tot uitlegproblemen. Niettemin verdient het aanbeveling specifiek aan te geven welke informatie geheim moet worden gehouden. De onderhandelingspartijen kunnen namelijk overeenkomen om het onderwerp van de onderhandelingen geheim te houden. Dit kan cruciaal zijn in overnamecontracten en in de projecten waarbij een innovatief product op de markt wordt gebracht. Zo hebben twee uitgevers, die in onderhandeling waren over een project om een nieuwe krant voor de Nederlandse markt te ontwerpen, hun geheimhoudingsbeding als volgt geformuleerd:

No announcements may be made about the Mirror's possible involvement in the de Krant project mithout the Mirror's prior approval. ${ }^{11}$

Partijen kunnen ook angeven dat de informatie die tijdens de onderhandelingen mordt verstrekt vertrouwelijk is. Een nadruk op de inhoud van de informatie kan van belang zijn in projecten waarbij er concepten van technologieën of ideeën worden besproken, vooral als deze nog niet door andere intellectuele eigendomsrechten zijn beschermd.

8. Walford/Miles [1992] 2 AC 128 (HL) 139 (Lord Ackner)

9. JSD Corporation PTE Ltd/AI Waha Capital PJSC, Second Waha Lease Ltd [2009] EWHC 583 (Ch), 2009 WL 648840.

10. Rb. Rotterdam 12 april 2017, ECLI:NL:RBROT:2017:3530 (A.L.T. Trading en Romar-International/Eneco).

11. HR 24 november 1995, ECLI:NL:HR:1995:ZC1890, NJ 1996/162 (Van Engen/Mirror Group). 
Ook kunnen de partijen in een letter of intent aangeven dat bepaalde informatie niet vertroumelijk is. In de lagere rechtspraak $^{12}$ zijn er voorbeelden van aansprakelijkheid in onrechtmatige daad wegens misbruik van informatie die tijdens onderhandelingen wordt verstrekt. ${ }^{13}$ In verband met de organisatie van het EK 2000 in Nederland en België moest er een camerasysteem worden aangelegd in het Feijenoordstadion. ${ }^{14}$ Het stadion nam contact op met Varel Security BV, waarna Varel een uitgebreide offerte uitbracht. Op de offerte vermeldde Varel dat deze vertrouwelijk was. Feijenoord was echter op zoek naar de beste aanbieding voor de laagste prijs. Het stadion trad dan ook tegelijkertijd in onderhandeling met Siemens. Ondanks de vermelding op de offerte van Varel verstrekte Feijenoord de offerte aan Siemens. Siemens kon met behulp van de verkregen informatie dezelfde technische oplossingen voor een aanzienlijk lagere prijs aanbieden, waarna Feijenoord de overeenkomst met Siemens sloot. Varel stelde Feijenoord aansprakelijk voor zowel de reeds geleden als de nog te lijden schade. Volgens het hof had de handelwijze van Feijenoord een onrechtmatig karakter. Het stadion werd aansprakelijk gesteld om de volledige door Varel geleden schade, zijnde het positief contractsbelang, te vergoeden. ${ }^{15}$ Een beding dat expliciet aangeeft dat bepaalde informatie niet vertroumelijk is, kan derhalve duidelijkheid scheppen indien er een geschil ontstaat over de manier waarop een van de partijen met de informatie omgaat.

Naar Nederlands recht hebben de onderhandelingspartijen geen plicht om de informatie die zij tijdens contractonderhandelingen verkrijgen als vertrouwelijk te beschouwen; er zijn althans geen voorbeelden in de rechtspraak waarin de maatstaven van redelijkheid en billijkheid op deze manier worden geinterpreteerd. Dit is echter anders in de soft law. Onder bepaalde omstandigheden hebben de onderhandelingspartijen een geheimhoudingsplicht met betrekking tot de informatie die is verkregen tijdens de onderhandelingen. Deze geheimhoudingsplicht bestaat zelfs als de partij die de informatie verstrekt niets over haar vertrouwelijke

12. Hof Den Haag 16 oktober 2002, ECLI:NL:GHSGR:2002:AJ3708, PRG 2003/6076; Hof Den Haag 29 januari 2003, ECLI:NL:GHSGR: 2003:AO1837, PRG 2004/6139; Hof Den Haag 28 januari 2004, ECLI:NL:GHSGR:2004:A07536, PRG 2004/6182.

13. De grondslag en de rechtvaardiging van de aansprakelijkheid in deze context werden wel betwijfeld. Zie P. Abas, noot bij Hof Den Haag 16 oktober 2002, ECLI:NL:GHSGR:2002:AJ3708, PRG 2003/6076, met verwijzing naar H.C.F. Schoordijk, Onderhandelen te goeder trouw, Deventer: Kluwer 1984, p. 42-43 en 61-63.

14. Hof Den Haag 28 januari 2004, ECLI:NL:GHSGR:2004:AO7536, Prg. 2004/6182.

15. Zie Hof Den Haag 28 januari 2004, ECLI:NL:GHSGR:2004:AO7536, Prg. 2004/6182, r.o. 12 en 15. karakter vermeldt. ${ }^{16}$ Artikel 2.1.16 van de Unidroit Principles of International Commercial Contracts (UPICC) geeft een voorbeeld van de relevante omstandigheden: A heeft interesse in een samenwerking met $\mathrm{B}$ of $\mathrm{C}$, die allebei grote autofabrikanten zijn. A treedt zowel met $\mathrm{B}$ als met $\mathrm{C}$ in onderhandeling. Tijdens de onderhandelingen verstrekt $\mathrm{B}$ aan $\mathrm{A}$ gedetailleerde informatie over een nieuw design van een auto. Alhoewel $\mathrm{B}$ niet eist dat A deze informatie als vertrouwelijk beschouwt, heeft $\mathrm{A}$ een plicht om deze informatie noch aan $C$ te verstrekken, noch in haar eigen productieproces te gebruiken. Wat de remedie betreft, kan op grond van artikel 2.1.16 UPICC zowel een negatief als een positief contractsbelang worden gevorderd. ${ }^{17}$

Zoals reeds opgemerkt, ligt een dergelijke verplichting niet voor de hand in het Nederlandse recht. Maar de Nederlandse rechter kan zich door de soft law laten inspireren. In dit geval kan een beding waaruit blijkt welke informatie niet vertrouwelijk is, mijns inziens de kans verminderen dat een geheimhoudingsplicht als een invulling van de (Nederlandse) redelijkheid en billijkheid wordt aangemerkt. Een specifieke formulering schept ook duidelijkheid over de bedoelingen van de partijen over de inhoud van de precontractuele redelijkheid en billijkheid. De exacte bepalingen geven dan ook een houvast over de geschonden belangen en de eventuele schade als de verbintenis niet wordt nagekomen.

\section{Onderhandelen met een voorbehoud}

Een letter of intent beoogt, althans vanuit het oogpunt van de onderhandelaars, de voortgang van de onderhandelingen te faciliteren, maar niet om de definitieve overeenkomst te sluiten. Partijen nemen dan ook een voorbehoud op in een clausule die subject to contract, subject to final agreement of subject to pritten agreement wordt genoemd. Dit beding geeft aan dat op het moment van het opstellen van de letter of intent de definitieve overeenkomst nog niet tot stand is gekomen. Zo'n beding wordt ook een totstandkomingsvoorwaarde genoemd. De partijen hebben dus nog geen overeenkomst gesloten; ze hebben ook geen voorwaardelijke verbintenissen in de zin van artikel 6:26 van het Burgerlijk Wetboek (BW) gecreëerd. ${ }^{18}$

In beginsel worden deze clausules in de rechtspraak zo uitgelegd dat bij het intreden of uitblijven van een han-

16. Zie voor deze mogelijkheid art. 2.1.15 en 2.1.16 UPICC (UNIDROIT Principles of International Commercial Contracts 2016, <www.unilex. info>); art. 2:302 PECL (O. Lando \& H.G. Beale (red.), The Principles of European Contract law, Parts I and II. Prepared by the Commission on European Contract Law, Den Haag: Kluwer Law International 2000); art. II. - 3:302, Comment B DCFR (Ch. von Bar \& E. Clive (red.), Principles, Definitions and Model Rules of European Private Law: Draft Common Frame of Reference (DCFR), Oxford: Oxford University Press 2010).

17. Art. 2.1.16 UPICC, Official Comment, Illustration 3.

18. Voor de bespreking van de gevolgen van de totstandkomingsvoorwaarden zie Tjittes 2016, p. 253-264. 
deling de overeenkomst niet tot stand komt. Deze uitleg ligt voor de hand indien duidelijk uit de omstandigheden blijkt dat de onderhandelingen nog niet zijn afgerond. Zo werd in een geschil, dat werd behandeld door de Rechtbank Midden-Nederland, onderhandeld over de koop van 21 vliegtuigen. Een letter of intent met een 'subject to'-beding werd opgesteld. Toen een van de partijen de onderhandelingen afbrak, stelde de andere partij dat een definitieve overeenkomst tot stand was gekomen. Volgens de rechter kon in beginsel worden vastgesteld dat er een koopovereenkomst was gesloten. De partijen hadden echter nog 'niets afgesproken over de prestaties van het vliegtuig en daarvoor gegeven garanties, onderdelen en de beschikbaarheid daarvan, onderhoud, reparaties, training (van piloten, onderhoudspersoneel)' en de op de klant toegesneden vormgeving van het vliegtuig. ${ }^{19}$ Volgens de rechter moest over deze belangrijke voorwaarden nog verder worden onderhandeld; er kon dus niet worden geconcludeerd dat er een overeenkomst tot stand was gekomen. Deze uitleg van een 'subject to'-beding legt de nadruk op de vrijheid van onderhandelingen. ${ }^{20}$

In een aantal gevallen worden de 'subject to'-clausules echter op een meer genuanceerde manier geïnterpreteerd. In de eerste plaats kan een voorbehoud niet worden ingeroepen indien dit naar maatstaven van redelijkheid en billijkheid onaanvaardbaar is. ${ }^{21}$ In de tweede plaats is de kans groot dat de rechter geen rekening houdt met het voorbehoud indien het sluiten van de definitieve overeenkomst door de partijen wordt beschreven als een formaliteit of een vormvereiste. ${ }^{22}$ Wanneer de laatste formaliteiten niet zijn vervuld, kunnen de partijen toch aan de definitieve overeenkomst verbonden zijn, met name als het onderhandelingsproces af is en de partijen op alle punten die bij een bepaald type transactie horen overeenstemming hebben bereikt.

Een clausule kan ook aangeven dat de inhoud van een letter of intent niet bindend is. Deze formulering wordt door de partijen vaak als een 'veilige haven'23 gezien, omdat deze benadrukt dat ze vrij zijn om de onderhandelingen af te breken, bijvoorbeeld:

19. Rb. Midden-Nederland 2 oktober 2013, ECLI:NL:RBMNE:2013:3861, NJF 2013/494. Zie ook Hof Den Haag 7 mei 2013, ECLI:NL:GHDHA: 2013:BZ9634, NJF 2013/241, r.o. 3.

20. HR 24 november 1995, ECLI:NL:HR:1995:ZC1890, NJ 1996/162 (Van Engen/Mirror Group). Zie ook M. van Hooijdonk \& R.J.P.L. Tjittes, Precontractuele aansprakelijkheid bij onderhandelen met een voorbehoud, in: B. Wessels \& S.Y.Th. Meyer (red.), Bedrijfsovername, Deventer: Kluwer 2009, p. 71 e.v.; Wessels 2010, par. 3.2-3.3; De Kluiver 1992, p. 15-24 e.v.; H.-J. de Kluiver \& C.A. Schwarz, Onderhandelen onder voorbehoud in het bijzonder met rechtspersonen, in: L.G. Eykman e.a., Onderhandelen, bemiddelen en schikken, Deventer: Kluwer 1998, p. 101; R.H.J. van Bijnen, Aanvullend contractenrecht (diss.), Tilburg 2005, <https://pure.uvt.nl/portal/files/682318/168372.pdf>, p. 335-343; M.R. Ruygvoorn, Afgebroken onderhandelingen en het gebruik van voorbehouden, Deventer: Kluwer 2009, p. 157-241; B. Wessels, Letters of intent, in: B. Wessels \& S.Y.Th. Meyer (red.), Bedrijfsovername, Deventer: Kluwer 2009, p. 260-262.

21. Tjittes 2016, p. 256.

22. Zie ook H. Stolz, Partij-invloed op het intreden of vervallen van voorwaarden, Contracteren 2016/4, p. 110-117

23. Van Bijnen 2005, p. 155.
We will proceed to make arrangements with counsel for each of the parties for the completion of the Interim Agreement (...) with the understanding that this letter of intent is of no binding effect on any party hereto. ${ }^{24}$

Door zo'n clausule kunnen partijen echter alleen regelend recht uitsluiten. Dit wil zeggen dat als het afbreken van onderhandelingen niet aanvaardbaar is vanuit het oogpunt van redelijkheid en billijkheid, een partij ondanks dit beding aansprakelijk kan worden gesteld. Een beding over het niet-bindende karakter van een letter of intent biedt derhalve geen veilige haven tegen de werking van het dwingend recht. Wel wordt het moeilijker te bepleiten dat een van de partijen er vertrouwen in heeft dat een overeenkomst tot stand zal komen. ${ }^{25}$

De vraag of het mogelijk is om de aansprakelijkheid door een contractueel beding te beperken (hetzij de aansprakelijkheid in onrechtmatige daad, hetzij contractuele aansprakelijkheid), dient zich ook aan indien een partij met het nakomen van de definitieve overeenkomst begint terwijl de partijen onder voorbehoud onderhandelen. Indien een van de partijen is begonnen met het nakomen van de definitieve overeenkomst, is de kans groter dat wordt vastgesteld dat de definitieve overeenkomst tot stand is gekomen. In Nederland komt het leerstuk van ongerechtvaardigde verrijking (art. 6:212 $\mathrm{BW})$ in deze context niet vaak in aanmerking. ${ }^{26}$ In de Verenigde Staten en in Engeland wordt de vergoeding van de kosten van de prestatie daarentegen het vaakst gevorderd als ongerechtvaardigde verrijking. ${ }^{27}$

Het verdient aanbeveling om een bepaling over de onderhandelingen onder voorbehoud op te stellen als wegwijzer tussen de verschillende manieren van uitleg en een duidelijke weergave te geven van de feiten die aanleiding geven tot het opstellen van een 'subject to'clausule. Het is tevens aan te raden om aan te geven melke bepalingen van een letter of intent als bindend bedoeld zijn (zoals geheimhouding en exclusiviteit) en welke clausules niet. ${ }^{28}$ Deze benadering schept mijns inziens ook voldoende duidelijkheid om een geschil te voorkomen. ${ }^{29}$ Daarnaast kunnen partijen in een letter of intent ook de belangrijkste punten noemen waarover nog geen overeenstemming is bereikt. Deze formulering helpt te voorkomen dat de letter of intent als een definitieve overeenkomst wordt uitgelegd.

24. Rennick/O.P.T.I.O.N. Care, Inc., 77 F.3d 30977 F.3d 309, 316 (C.A.9 1996).

25. HR 24 november 1995, ECLI:NL:HR:1995:ZC1890, NJ 1996/162 (Van Engen/Mirror)

26. HR 18 april 1969, ECLI:NL:HR:1969:AC4925, NJ 1969/336 (Katwijk/ Westdijk). Zie ook Tijttes 2016, p. 248.

27. Pannebakker 2016, p. 171, 228.

28. Fontaine \& De Ly 2009, p. 55.

29. Zie Pannebakker 2016, p. 243-244. 


\section{Kosten verdelen en anticiperen op aansprakelijkheid}

Complexe onderhandelingen kunnen tot kosten leiden. Voordat wordt besloten om met de andere partij in zee te gaan moet er soms een due diligence, feasibility study of een ander voorbereidend onderzoek plaatsvinden. Een duidelijke afspraak over de manier waarop de kosten worden verdeeld, heeft praktische nadelen - zelfs indien de transactie goed verloopt. Als de onderhandelingen worden afgebroken, wordt de verdeling van de kosten voor de aansprakelijkheid en vergoeding relevant. Er zijn meerdere manieren om de kosten te verdelen. Ten eerste kunnen de partijen overeenkomen dat elke partij risico draagt voor de kosten die worden gemaakt tijdens de onderhandelingen en deze voor eigen rekening neemt. Een dergelijk beding behelst mijns inziens niets meer dan een herhaling van het wettelijk kader. Dit beding staat de mogelijk beperkende werking van de redelijkheid en billijkheid dan ook niet in de weg. Ten tweede kunnen de partijen overeenkomen dat de kosten (deels) op een andere manier worden verdeeld indien de resultaten van een preliminair onderzoek (zoals due diligence) negatief zijn. Ten derde kunnen de partijen een bedrag afspreken dat het maximum is van de kosten die een partij mag maken. Alle kosten boven het maximum worden dan op eigen risico gemaakt, bijvoorbeeld:

If $D B$ breaches any of its obligations in this paragraph or if during the Lock-Out Period DB withdraws from negotiations with NBM for the sale of the Property, NBM shall be entitled to recover all of its costs and expenses relating to the investigation and negotiation of the proposed acquisition by it of the Property, however in no case more than EUR 300,000.00 in total, without the possibility of any further claims of any kind of $N B M .^{30}$

De tweede en de derde formulering zijn direct verbonden met de vraag naar de aansprakelijkheid. Daarom kunnen deze clausules niet garanderen dat de rechter ze letterlijk volgt. Voor zover er gronden bestaan voor aansprakelijkheid voor afgebroken onderhandelingen die niet onder de regeling van dit beding vallen, ontstaat het risico dat de bedingen zonder praktische gevolgen blijven.

Naast het verdelen van de kosten proberen de onderhandelingspartijen ook de aansprakelijkheid op een brede manier te regelen (namelijk door deze te beperken), zoals in de volgende clausule:

In the event that a Secondary Sub contract is not concluded we shall reimburse only your reasonable and substantiated direct costs of complying with this instruction until it is revoked. We mill not reimburse any other expenditure cost or loss mhatsoever. This limitation includes mithout derogating from the generality of the foregoing any claim for breach of contract, loss of profit, loss of contract, loss of expectation or othermise. ${ }^{31}$

Dit beding kan invloed hebben op de aansprakelijkheid. ${ }^{32}$ Terwijl de 'klassieke' aansprakelijkheid voor het ongeoorloofd afbreken van onderhandelingen een aansprakelijkheid sui generis betreft, die het meest lijkt op de aansprakelijkheid op grond van onrechtmatige daad, kan een letter of intent gevolgen hebben voor de grondslag van de aansprakelijkheid. De grondslag van de aansprakelijkheid wordt bij een letter of intent contractueel. Een dergelijke clausule legt uit wat de gerechtvaardigde verwachtingen van de partijen tijdens de contractonderhandelingen zijn en kan worden uitgelegd als de inhoud die de partijen zelf aan de precontractuele redelijkheid en billijkheid geven. Deze bepaling weegt dan ook zwaar bij het vaststellen van de aansprakelijkheid. Maar hoe meer de aansprakelijkheid, die door het beding wordt beperkt, op niet-regelend recht is gebaseerd, hoe minder er in de rechtspraak rekening lijkt te worden gehouden met een beding dat aansprakelijkheid beperkt.

Twee situaties vormen mijns inziens de meest opvallende uitzonderingen op de mogelijkheid om de aansprakelijkheid te beperken. Ten eerste dient de beperking van de aansprakelijkheid niet te worden bekrachtigd indien een partij alleen met de andere partij onderhandelt met de bedoeling om de informatie te verkrijgen. Het Amerikaanse recht kent bijvoorbeeld een tort of misappropriation of trade secrets die in deze situaties relevant is. In de Nederlandse literatuur zijn deze situaties besproken, ${ }^{33}$ maar de rechtspraak levert hiervan weinig voorbeelden. Ten tweede dient de beperking van de aansprakelijkheid niet te worden bekrachtigd indien een partij alleen met de andere partij onderhandelt met de intentie om te voorkomen dat de andere partij met een concurrent in onderhandelingen treedt. De Unidroit Principles of International Commercial Contracts, ${ }^{34}$ Principles of European Contract $\mathrm{Law}^{35}$ en Draft Common Frame of Reference ${ }^{36}$ sluiten ook aan bij deze twee situaties.

De remedie tegen de schending van een contractueel bindende bepaling van een letter of intent beperkt zich in de praktijk voornamelijk tot het vergoeden van de kosten die zijn gemaakt tijdens de onderhandelingen (of, zoals in sommige gevallen, tot teruggave van de prestatie die is verricht). De Hoge Raad heeft opgemerkt dat de aansprakelijkheid voor afgebroken onderhandelingen 'een strenge en tot terughoudendheid nopende maatstaf'

31. Bennett (Electrical) Services Limited/Inviron Limited [2007] EWHC 49 (TCC), 2007 WL 1518029

32. Voor een voorbeeld zie Hof Den Bosch 8 april 2014, ECLI:NL:GHSHE: 2014:988, RI 2015/49.

33. P. van Schilfgaarde, Precontractuele goede trouw. Afgebroken onderhandelingen, Ars Aequi 1983, p. 758-763; A.G. Castermans, Walford v Miles, European Review of Private Law 1994, p. 290-295; J.H. Nieuwenhuis, Het dieptepunt: Plas/Valburg, Ars Aequi 2010, p. 288-290.

34. Art. 2.1.15(3) UPICC.

35. Art. 2:301(3) PECL.

36. Article II.-3:301(4) DCFR. 
dient te zijn. ${ }^{37}$ In uitzonderlijke gevallen kan een partij onder het Nederlandse recht worden veroordeeld tot winstafdracht, of een rechterlijk bevel krijgen tot dooronderhandelen. ${ }^{38}$ De winstafdracht wordt ook in de soft law-instrumenten vastgelegd. ${ }^{39}$

Er dient te worden opgemerkt dat indien de partijen overeenkomen een bepaald bedrag te betalen als de transactie niet doorgaat, zo'n beding als een boetebeding kan worden uitgelegd. Zowel dit beding als de boete wordt ook wel break-up fee genoemd. Daarop kunnen de artikelen 6:91 e.v. BW van toepassing zijn; op grond van artikel 6:94 BW kan de rechter de boete matigen. ${ }^{40} \mathrm{De}$ Hoge Raad heeft vastgesteld dat de rechter de boete mag matigen voor zover de break-up fee niet proportioneel is ten opzichte van de beoogde transactie, waarbij rekening wordt gehouden met alle omstandigheden van het geval. ${ }^{41}$ Verder dient de rechter rekening te houden met de aard van de overeenkomst, de inhoud en de strekking van het beding, en de omstandigheden waaronder het is ingeroepen. ${ }^{42}$

\section{Geschillenclausule}

Een geschillenclausule is een van de boilerplatebepalingen waarbij de partijen een rechtskeuze en een forumkeuze opnemen. Een rechtskeuze ten aanzien van de onderhandelingen verdient vooral bij internationaal contracteren aanbeveling, omdat de onderhandelingsfase in verschillende rechtsstelsels op uiteenlopende manieren wordt geregeld. In de rechtspraak zijn er voorbeelden van zulke keuzes, die door de rechter werden gevolgd. ${ }^{43}$ Daarnaast verdient het aanbeveling een forumkeuze in een letter of intent op te nemen of een arbitrageclausule op te stellen om een discussie te voorkomen over de vraag welke rechter bevoegd is tot beslechting van de gerezen geschillen. In de Nederlandse rechtspraak zijn

37. HR 12 augustus 2005, ECLI:NL:HR:2005:AT7337, NJ 2005/467 (CBB/ JPO). Zie ook T. Hartlief, Aansprakelijkheid ter zake van afgebroken onderhandelingen: terughoudendheid troef, Ars Aequi 2005, p. 1027-1034.

38. D. de Boer, De verplichting tot dooronderhandelen, in: W.H. van Boom, J.H. van Dam-Lely \& S.D. Lindenbergh (red.), Rake remedies: Opstellen over handhaving van rechten, naleving van plichten en sanctionering van verkeerd gedrag in het privaatrecht, Den Haag: Boom Juridische uitgevers 2011, p. 105; M.R. Ruygvoorn, De vordering tot dooronderhandelen nader belicht, Ars Aequi 2012, p. 613-620.

39. Zie bijv. art. 2.1.16 UPICC.

40. Voor een rechtsvergelijkend perspectief zie H.N. Schelhaas, Het boetebeding in het Europese contractenrecht, Deventer: Kluwer 2004. Zie ook Hof Den Bosch 8 april 2014, ECLI:NL:GHSHE:2014:988, RI 2015/49.

41. HR 18 april 2003, ECLI:NL:HR:2003:AF2161, NJ 2003/286 (RNA/ Westfield).

42. HR 27 april 2007, ECLI:NL:PHR:2007:AZ6638, RAV 2007/12 (Intrahof/ Bart Smit).

43. HR 24 november 1995, ECLI:NL:HR:1995:ZC1890, NJ 1996/162 (Van Engen/Mirror Group); Hof Amsterdam 26 april 2011, ECLI:NL:GHAMS: 2011:BQ5836. Zie ook M. Zilinsky, Forumkeuzebedingen en andere bevoegdheidscheppende clausules in internationale contracten, in: B. Wessels \& T.H.M. van Wechem, Contracteren in de internationale praktijk, Deventer: Kluwer 2011, p. 453; Asser/Kramer \& Verhagen 10-III, 2015/952. er voorbeelden van geschillen waarbij de Nederlandse rechter zijn bevoegdheid op een forumkeuze in een letter of intent had gebaseerd. ${ }^{44}$

Bij internationaal contracteren wordt zo'n beding als een aparte overeenkomst beoordeeld, op grond van het leerstuk van severability. ${ }^{45}$ Dit wil zeggen dat zelfs een nietige of een niet-bindende letter of intent een bindende forumkeuze kan bevatten. Als er een geschil zou ontstaan over het bindende karakter van bijvoorbeeld een voorbehoud of exclusiviteit, dan zou de door de partijen aangewezen rechter bevoegd zijn om van het geschil kennis te nemen.

\section{Tot slot}

Contractuele bedingen die betrekking hebben op de onderhandelingsfase, verklaren de precontractuele verwachtingen van de onderhandelingspartijen. Indien er een geschil over afgebroken onderhandelingen ontstaat, kan de inhoud van de precontractuele redelijkheid en billijkheid in het licht van bedingen worden uitgelegd. De hoogste prioriteit dient dan ook aan de partijautonomie te worden gegeven. Met het oog op de partijautonomie verdient mijns inziens de grammaticale interpretatie van bedingen de voorkeur. De grammaticale, letterlijke interpretatie is echter alleen mogelijk als de bedingen die betrekking hebben op de onderhandelingsfase specifiek en gedetailleerd zijn geformuleerd.
44. Zie bijv. Rb. Amsterdam 5 maart 2013, ECLI:NL:RBAMS:2013:CA2529.

45. Ook de instrumenten die het internationaal privaatrecht bevatten, zijn op het leerstuk van severability gebaseerd. Zie art. 3(d) Verdrag inzake bedingen van forumkeuze, Den Haag, 30 juni 2005, Trb. 2009, 31; art. 25(5) Verordening (EU) 1215/2012 betreffende de rechterlijke bevoegdheid, de erkenning en de tenuitvoerlegging van beslissingen in burgerlijke en handelszaken (herschikking), PbEU 2012, L 351/1. Zie ook art. II en $\mathrm{V}(1)$ (a) Verdrag over de erkenning en tenuitvoerlegging van buitenlandse scheidsrechterlijke uitspraken, New York, 10 juni 1958, Stb. 1893. 